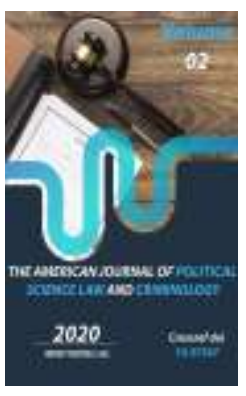

\title{
Prospectives Of Trust Management Of Property In Uzbekistan
}

\author{
Akmal Akramov \\ Lecturer At Tashkent State University Of Law, Uzbekistan
}

Journal Website: http://usajournalshub.c om/index,php/tajpslc

Copyright: Original content from this work may be used under the terms of the creative commons attributes 4.0 licence.

\section{ABSTRACT}

In this research work, the concept of trust management of property, its basic principles, the role and importance of the norms of legislation in the field of trust management of property in the conduct of entrepreneurial activity are studied. At the same time, legislation in the field of business law and civil law norms related to trust management of property were analyzed.

Legislative acts and the associated law-enforcement practice of some foreign countries in the field of trust management of property in conducting entrepreneurial activities were thoroughly studied, and proposals were developed for further improving national legislation in this area.

\section{KEYWORDS}

Trust management of property, Civil code, public benefit, executor of a will,guardianship, property rights, inheritance, civil law regulation, ownership of the property.

\section{INTRODUCTION}

The institution of trust management of property and the contract of trust management are essentially interrelated categories. Article 850 of the Civil Code lists the grounds for the establishment of trust management of property and the first of them is the "trust management agreement between the founder and the trust manager".Although this article presents other facts as the basis for the establishment of trust management of property, it is necessary to conclude a contract for trust management of the property 
between the managing director and the trust manager. For example, the introduction of trust management of property by a court decision involves the determination of who the founder is, the trust manager and the beneficiary, and the management of the property in the interests of the beneficiary, and the agreement between the parties.

In this case, trust management will also depend on other bases on which it is implemented. In particular, trust management may be established by the "decision of the guardianship and trusteeship authority to designate the custodian's property" and an agreement between the trusteeship and the trustee. This is provided by Article 35 of the Law of the Republic of Uzbekistan dated January 2, 2014 No. ZRU-364 "On Guardianship and Trusteeship".

With reference to the stages of development of the Fiduciary Property Rights Basis, it is necessary to refer to UK law. Because trust management of property, the English Trust Institute was first established in England and later developed and adopted a number of laws dedicated to the institution.In particular, the Law on Trusted Property, which regulates the law on trustees in England and Wales, adopted on April 9, 1925, the Real Estate Trust and Trustee Assignment Act of 1996, the Trust Recognition Act of 1987. The Law on Trusted Owners of 2000, 2000 provides important norms for the reliable management of property.Later this institution began to be used not only in the countries of the EnglishAmerican legal system, but also in the

\footnotetext{
${ }^{1}$ Sokol P.V., Shakirova M.R. Legal nature of institutions of trust (trust) and trust management: experience of comparative research // Notarial Bulletin / http://old.notariat.ru/start.htm / 07.04.2011..

${ }^{2}$ Thomas G., Hudson A. The law of trusts. N.Y., 2004. P. 13 /

Quoted from the following source: Benevolenskaya Z.E.
}

countries of the continent. In the last 20 years of the last century, the rules of trust management of property have been reflected in the legislation of Russia, Germany, Japan, the Netherlands, Italy and other countries. However, the institution of trust management in these countries has not been traditionally represented as "clean". In the legal systems established on the basis of the Roman right, the institute of trust management has led to the introduction of legislation in the specific and other approaches and legal mechanisms. ${ }^{1}$

Most researchers today recognize that there are four elements that can be used to describe a trust property or a "clean" trust:

(a) Trust property shall be regulated by the right of justice;

(b) The beneficiary's right to property is protected by the right to justice;

(c) Obligations are entrusted to the trustee under the right of justice;

(d) The trustee's obligations are inherently (ie based on the ransom). ${ }^{2}$

However, the legal definition of the trust is not provided in English law or in the judicial practice of that country. Most British authors give a similar definition to this notion. In particular, Jennings believes that a trustee is an honest and voluntary undertaker, but the law imposes an obligation to do so if it is accepted, ie the right of ownership and management of the property in the interests of other persons or persons. ${ }^{3}$

Definition, classification of species and qualifying criteria of trustworthiness (trust) on the right of Great Britain // Journal of Russian law. 2008. - № 9. - p. 32.

3Jenks E. English law / Cit. by: MikheevaL.Yu. Trust management of property. - M .: 1999 .-- S. 5 
A. Anderhill writes that trust is an obligation that must be managed by the interests of third parties (beneficiaries), who have the right to demand the compulsory execution of property transferred by one person (trustee) to another (founder). ${ }^{4}$ Judge Hayton argues that "a trust governed by English law is an obligation under the law of justice, and that the trustee has the right to demand fair administration of the obligation of the founder and beneficiary to administer the property." ${ }^{5}$

It is worth noting that the property trust agreement is a relatively new institution for civil law and science in Uzbekistan. In addition, this institution has made a difference in understanding of property rights between continental and Anglo-American law systems, and is particularly relevant in today's legal system.At the same time, it is the science of civilization to identify the pros and cons of trust management of property in the system of continental property management in the system of trust management of property in the Anglo-American legal system, which is also known as trust. is one of the objectives. The majority of jurists who have studied the history of the Trust Institute argue that trust management of property arose in England in the 12th and 13th centuries. It is well known that the land was inherited only by the heir. Passing various obstacles to divide land parcels for a different purpose presented some challenges. As a result, a trust institution was established to "circumvent" these obstacles and to violate established norms. ${ }^{6}$ For example,

${ }^{4}$ McLoughlin P., Rendell K. Lawof Trusts / Cited. by: Funtikova N.V. On the regulation of trust and a property trust agreement // Journal of Russian Law. 2002. - No. 12. - P. 85.

${ }^{5}$ Hayton D.J. Developing the obligation characteristic of the trust // The Law Quarterly rewiew. 2001. - P. 107.

${ }^{6}$ Civil and commercial law of capitalist states: Textbook. 2nd edition, rev. add. - M .: 1992. - P.236; Naryshikina R.L. Trust after the introduction of the Institute for Trust Management of Property, V.Dozortsev noted that "trust management of property, trust" has been established in England during the Middle Ages, and there were obstacles to the emergence of certain property owners. This institution was created in English law to enable it to be circumvented, and it was only through this that the proprietorship was strengthened.Dozortsev went on to argue that the trust trust property was not formally formalized before it was incorporated into the law, otherwise the violation of the law would be obvious, and the right of informal ownership with only the owner " "trust" arises from the relationship of trust between the entities. ${ }^{7}$

True, some authors argue that reliable property management existed in Roman law. For example, KI Sklovsky noted that in the Middle Ages, through the continuous efforts of Roman promoters (glossators), there was a "split right" for property, that is, the property rights were divided into two active and passive rights.

According to KI Sklovskiy, his views on the impact of the Roman right on the establishment of an institute of trust management of property in English law were hardly supported by other lawyers. ${ }^{8}$ At the timeG.Shershenevich noted that in the process of analysis of the English legal system the English law developed independently, the basis of English law was directly related to the

property in the civil law of England and the United States. - M .: 1965 .-- P.4.

${ }^{7}$ Dozortseva V.A. Trust management of property (chapter 53) // Civil code of the Russian Federation. Part two. Text, comments, alphabetic subject index / Ed. O.M. Kozyr, A.L. Makovsky, S.A. Khakhlova. -M .: 1996. -S.530.

${ }^{8}$ Sklovsky K.I. Property in civil law. - Stavropol: 1994 .--P. 72. 
results of legal proceedings. ${ }^{9}$ This view of GFShershenevich was supported by other scientists. As a result of the peculiarities of the judicial system in England, reliability of property management, E. Sukhanov said:

"Property management can be regarded as part of the notion of fairness between the trustee and the owner, and the courts have paid more attention to these concepts in the settlement of disputes, and the courts have linked justice to the notions of 'trust' - case law. because of their actual existence." ${ }^{10}$

The history of establishment and development of trust management can be seen in AngloAmerican law. This right also states that the establishment and development of the Trust Institute depends on the English judiciary and justice.In the legal literature ${ }^{11}$ it can be observed that the stages of development of trust management of property are divided into four:

The first step is to exercise the exclusive right to land. This right arose after the Normandy War (XI-XII centuries). But during these periods, the courts did not protect the rights of the owners. The owner did not have the right to recover damages from the trust manager. Although the parliament drafted and enacted various laws during this period, these laws did not contain norms defining the rights of the owner to the person using the property, but only the norms prohibiting the owner to transfer his property to another person. For example, the law of 1376 stipulates that the debtor's husband may be taken away by the

${ }^{9}$ Shershenevich G.F. Textbook of Russian civil law. Ninth edition. M.: 1911 .-- S. 36.

${ }^{10}$ Civil law. V 2 t. T. II. Textbook. - S. $491 .$. creditor and transferred to a third party for trust management. included.

The second stage, which took place in the early fifteenth century, recognized the Lord Chancellors' right to believe that property would be managed by another person as a means of struggle against the feudal lords. During this period, the right to "trust" was protected by the court. All disputes arising out of the Trust relationship have been settled in the courts of justice. The property is mainly divided into two areas of land, that is, the legal property belonging to the owner and the property of the person entrusted with the management of the property - "fair" property.

The third stage is related to the adoption in England in 1536 of the Law on the Trust Management of Property. The purpose of adopting this law was to change the previous form of trust management of property and to regulate certain legal relations of this institution. After the adoption of this law, all disputes arising from the "trust" were transferred from the "court of justice" to the courts of general jurisdiction. But the execution of the law remained with the Lord Chancellor. The chancellor, in turn, relied on the right to "justice." The general courts relied not on the rule of law, but on the primary right - the right to "justice". Only in the XVII century began to act in accordance with the norms of this law. At the same time, the regulation of legal relations "trust" returned from the courts of general jurisdiction to the courts of "justice", and these courts began to resolve disputes on the basis of the right of "justice".

\footnotetext{
${ }^{11}$ Austin Wakeman Scott and Austin Wakeman Scott, Jr. Select Cases and Other Authorities on the law of trusts. FifthEdition. Boston, Toronto. 1966. - P. 2-3.
} 
The fourth stage dates back to the seventeenth century. During this period, after the abolition of the feudal system (1660), "trust" relations began to apply to property other than land. The Trust has been modernized and the scope of the Trust's rights has expanded.

The above steps indicate that the institution of trust management of property has no relation to Roman law. This institute shows that the development of England was directly based on the actions of officials aimed at regulating relations between classes in society. By the way, EA Sukhanov stated that "in no country, in Europe and even in the history of Russian legislation has there been a case when the law is divided into" general "law and" justice "law. ${ }^{12}$ There was a norm in continental law that "there can be no two types of rights to the same property." That is, property rights could not be divided in relation to property.

In our opinion, the trust management of property can be determined on various grounds, for example, it can be a will, a contract. On this basis, the interests of the person who manages the property and the owner will be taken into account. In determining the trust management of the property, the owner grants all the rights related to the management of the property to the person who trusts the property. The owner may assign the right to free management of the property to the person who manages the property, specifying the purpose of management or indicating that it will bring a certain benefit.

The essence of the concept of trust management in Anglo-American law is that the

${ }^{12}$ Civil law. V 2 t. T. II. Textbook. - S. $491 .$. person who transfers the property to the trust manager - the founder - is the owner, and the person by whose interests - is thebeneficiary. In this case, the owner owns the propertysubmits to the management of another person for the benefit of the beneficiary. In this case, the beneficiary may also be the owner himself.

There is no notion that you have to be a clear individual as a beneficiary. Beneficiaries may also be uncertain individuals. Such "trusts" are considered public trusts. That is, it can also be assessed as sponsorship trusts. For example, trusts can be designated for health or cultural events. If the interests of a particular person are envisaged in a private trust, the public trust, which is in the interests of society, may also be applied in practice. ${ }^{13}$

Legal relations of trust management of property (trust) are widely used in various areas of property turnover in countries based on the Anglo-American legal system. In particular, the right of trust management of property is widely used in the establishment of large corporations. The movement began in 1892 at Standard Oil in the United States. The shareholders of 40 companies have agreed to transfer the management of their shares to a trust. In return, shareholders received certificates confirming the relationship between the person trusted to manage the property and more income. In turn, those entrusted with the management of the property were given the right to run the company.

Trusts are also used to organize the activities of securities portfolios, pension funds, economically insolvent (bankrupt)

${ }^{13}$ Civil and Trade Provost of the Capitalist States: Textbook. - M .: 1993. - S. 236, 240. 
organizations. Holding companies are also established on the basis of trust relations. Such companies have the status of a legal entity, taking over the shares of other companies, the management of property to a trustee, and are engaged in the activities of these companies.

There are also constructive forms of trust management. That is, the concept of special or special trust is applied in practice. Such a form of trust can be seen in the relationship between the principal and the agent, the company and its directors, members of the partnership, the principal and the attorney, the guardian and the ward, and so on. In a trust management relationship, one person has the opportunity to increase wealth at the expense of that person by acting in the interests of the other person. ${ }^{14}$

In the essence of this legal relationship, the person entrusted with the management of the property acts as the owner of the property in the management and circulation of the property. A trustee may make full use of the property and enter into various agreements relating to that property (except for the right to dispose of the property, alienate it). A person entrusted with the management of the property shall not have full ownership of the property.

The trustee must report to the beneficiary on the property under management. In addition, the trustee is obliged to transfer to the beneficiary all the remaining profit after deducting the costs and expenses in the property management activity.

English law has the principle of operating without pay by a trustee (the contract may

${ }^{14}$ Civil Code of Quebec. M., 1999. - p. 202-220. provide for a reward), but U.S. law provides for a fee-based operation.

The property transferred to the trust must be managed separately from the trustee's own property. The trustee shall be liable for the damage caused to the beneficiary as a result of improper performance of its obligations. In cases of abuse of power, the issue of criminal liability of the trust manager may also be resolved.

In cases where the established purpose has been achieved, the agreed period has expired, the beneficiary has died, and in other cases, the relationship of trust management of the property is considered terminated and the contract is terminated. The circumstances of termination of such transactions shall be specified in the contract.

The concept of division of property into parts in trust management of property exists in the right of "trust". For example, if the management and use part of the property belongs to the person entrusted with the management of the property, the second part, ie the part of the profit and income from the use of the property, belongs to the beneficiary.

Although Canadian law is based on the AngloAmerican legal system, the division of property into partsthere is a situation of non-compliance with the concept. In particular, trust relations are not recognized in the civil law of the Canadian province of Quebec. Articles 12601370 of the Civil Code ${ }^{15}$ of this country detail the relationship between fiduciary (trust) and the management of another's property. In this case, the founder separates his property or part of the property and builds another property. This new property, set aside for a

${ }^{15}$ Civil Code of Quebec. M., 1999. - p. 202-220. 
specific purpose, is handed over to the fiduciary manager. The fiduciary manager receives, uses, and manages this property. The founder and the fiduciary do not have property rights over this property (Articles 1260, 1261 of the Quebec FC).

Fiduciary is established for personal or public benefit. When a fiduciary is established for personal gain, it should be understood that the memory of the deceased or any other personal interest is defined as the purpose of pension benefits or benefits to shareholders, employees, society and members of the association. A fiduciary established in the public interest shall mean the public interest. For example, the proceeds from a fiduciary are used for future cultural, religious, educational, or scientific activities. In this case, the profit or management of the founder or fiduciary is not set as the primary objective. (Articles 1266, 1268-1270 of the Quebec FC).

A fiduciary manager does not have property rights in relation to fiduciary property. He only exercises the right to manage someone else's property. The fiduciary manager manages the documents related to the management of the property on his own behalf, controls the property, takes measures to ensure the targeted maintenance of the property. (Article 1278 of the Quebec FC).

In addition to Quebec's civil law, we can see the introduction of some contradictory norms into the Anglo-American legal system in the legislation of countries that are not based on the Anglo-American legal system. For example, if we look at German law, he noted that in Germany, too, the legal relationship between the owner and the owner of the property is regulated. "In such a relationship, the owner can be the owner of the property or the person who manages the property of another. Their relationship is governed by a mutual agreement or other document. Profits from property management activities are distributed between the owner and the person to whom the property management is entrusted. This form of relationship is mainly used to transfer the legal status of the ownerfounder to a person entrusted with the management of the property. For example, if the owner is a foreign national and does not have the citizenship of the state in which the property is located or is unable to operate in the territory of that state, he cannot manage it. In this respect, the management of the property is entrusted to the person entrusted with the management of the property. ${ }^{16}$

In short, the Anglo-American legal system, in contrast to the continental legal system, followed the principle of the division of property rights over property. In this case, the property right can be divided between the owner and the person who enters into a contract with him, and as a result, this situation in some sense endangers the property rights of the owner. Unlike Anglo-American law, the continental legal system is unique and indivisible, and in a sense ensures the supremacy of property rights. However, in recent times, harmonization in the global legal system has had a significant impact on the convergence of legal systems, which highlights the need to study and research the trustspecific legal mechanisms in the AngloAmerican legal system.

${ }^{16}$ See id. $-42 \mathrm{p}$. 
At the stage of gradual development of the provisions of the contract of trust management, certain features of this contract have been used in civil law in a number of constructions, in particular, in civil law relations such as "loss of a citizen", "guardianship and trusteeship", "executor of a will". From the civil-legal point of view, trust management is the adoption of the rules of trust from the general legal system in accordance with the continental legal system.

\section{REFERENCES}

1. Sokol P.V., Shakirova M.R. Legal nature of institutions of trust (trust) and trust management: experience of comparative research // Notarial Bulletin / http://old.notariat.ru/start.htm

07.04.2011..

2. Thomas G., Hudson A. The law of trusts. N.Y., 2004. P. 13 / Quoted from the following source: Benevolenskaya Z.E. Definition, classification of species and qualifying criteria of trustworthiness (trust) on the right of Great Britain // Journal of Russian law. 2008. - № 9. - p. 32.

3. Jenks E. English law / Cit. by: Mikheeva L.Yu. Trust management of property. - M .: 1999 .-- S. 5

4. McLoughlin P., Rendell K. Lawof Trusts / Cited. by: Funtikova N.V. On the regulation of trust and a property trust agreement // Journal of Russian Law. 2002. - No. 12. - P. 85.

5. Hayton D.J. Developing the obligation characteristic of the trust // The Law Quarterly rewiew. 2001. - P. 107.

6. Civil and commercial law of capitalist states: Textbook. 2nd edition, rev. add. - $M$ : 1992. - P.236; Naryshikina R.L. Trust property in the civil law of England and the United States. - M .: 1965 -- P.4.

7. Dozortseva V.A. Trust management of property (chapter 53) // Civil code of the Russian Federation. Part two. Text, comments, alphabetic subject index / Ed. O.M. Kozyr, A.L. Makovsky, S.A. Khakhlova. -M .: 1996. -S.530.

8. Sklovsky K.I. Property in civil law. Stavropol: 1994 --- P. 72.

9. Shershenevich G.F. Textbook of Russian civil law. Ninth edition. - M .: 1911 .-- S. 36.

10. Civil law. $V_{2}$ t. T. II. Textbook. - S. 491..

11. Austin Wakeman Scott and Austin Wakeman Scott, Jr. Select Cases and Other Authorities on the law of trusts. Fifth Edition. - Boston, Toronto. 1966. - P. 2-3.

12. Civil law. V 2 t. T. II. Textbook. - S. 491..

13. Civil and Trade Provost of the Capitalist States: Textbook. - M .: 1993. - S. 236, 240.

14. Civil Code of Quebec. M., 1999. - p. 202220. 